\title{
Amidochlorination of 4-O-Azidoformyl-D-pseudoglycals with Iron (II) Chloride and Chlorotrimethylsilane ${ }^{\dagger}$
}

\author{
Hỵun Woog Chung, Goo Soo Lee, and Bong Young Chung \\ Dinision of Chemistrv and Wolecular Engineering. Department of Chemistry. Sorea Lniversitv. Seoul 136-701, Sorea \\ Received Hav +, 2002
}

Key Words : Amidoclilorination. 4-O-Azidoformyl-D-pseudoglycals, lron (ll) chloride, sw Addition

Intramolecular photolysis or thermolysis of simple ally lic axidoformates affords axiridine derivatives which further rearrange to the ring-opened products or react with nucleophiles to produce 1.3-oxazolidin-2-one derivatives. ${ }^{1-5}$ Intramolecular thermoly sis of azidoformatc group with an olefin produces axiridine derivatives ${ }^{t i}$ and intermolecular photolysis of ethyl aridoformate with an olclin in the presence of a trace of water affords 1.2-amidoalcohols. ${ }^{7}$ Intramolccular photocycloaddition of carbamoyl aride and an olelin also affords aziridine derivalives. ${ }^{.}$

Application of these inter- or intramolccular photolysis reactions to $\mathrm{D}$-glvcals has also becn reported. Intramolccular photoly sis of 3-O-azidoformy - $-4.6-O$-isopropy lidenc-D-allal in alcohol affords 2-anido-2-deoxy-D-allopyranosides in regio and stercoselective manner. ${ }^{9.15}$ Intermolccular photolysis of D-glucal or D-galactal derivatives with elhyl azidoformatc in alcohol also produces 2-amido-2-dcoxy-Dglycopy ranosides. ${ }^{11.12}$

Reaction of simple allylic aridoformates with 0.1 cquivalents of iron (II) chloride and 1.5 cquivalents of chlorotrimethylsilane (TMSCl) in ethanol is known to produce 4chloroalkyl-1.3-oxayolidin-2-one derivatives in moderate yicld. ${ }^{13}$ We intended to apply this methodology to the various unsalurated monosaccharides having allylic alcohol moicty because monosaccharides having amino or nitro groups at 2-. 3-. 4-. or 6-position arc important structural components of the glycopeptide antibiotics. ${ }^{1+}$ Hercin we report the synthesis of cyclic carbamates of 3-amino-2chloro-2.3-didcoxy-D-glycopy ranosides from D-pscudoglycals (2.3-dideoxy-D-threo(or enthro)-hex-2-cnopyranosides) with iron (II) chloride and TMSCI.

\section{Results and Discussion}

Tri-O-acetyl-D-glucal (1) was Ferricr-transformed ${ }^{15}$ and deacetylated to give ben $\%$ ] $\alpha$-D-pscudoglucal (2). Sclective protection of the 6-liydroxyl group of 2 with t-butyldiphenylsily] chloride (TBDPSCI) produced compound 3 . Monotosylation of the 6-hydroxyl group of 2 followed by the reduction with lithium aluminumhydride afforded 6deoxy compound 4 . Inversion of the configuration of the 4hydroxyl group of 3 and 4 by Mitsunobu method ${ }^{16}$ with

l'] his papet is dedicated to the late P'rofessor Sang C']hul SThim with respect - a remarkable gentleman and a truly exceptional scientist.

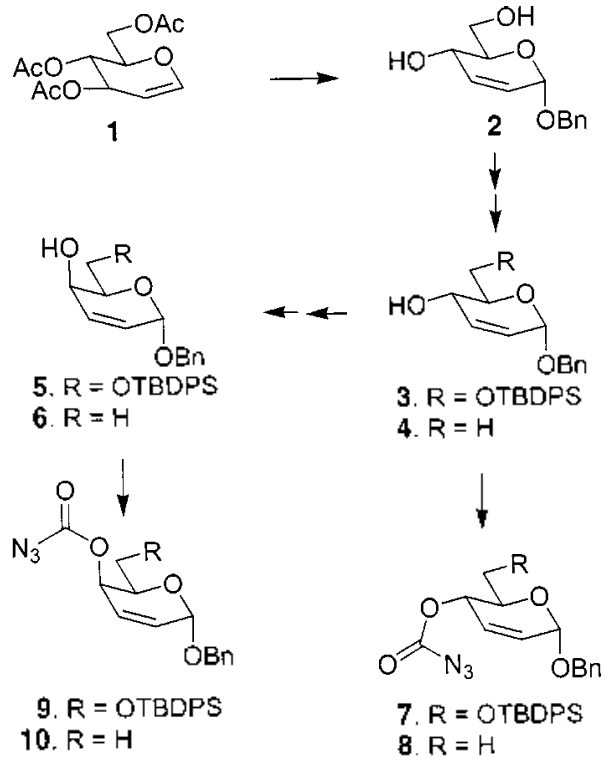

Scheme 1. Preparation of D-pseudoglycals.

benzoic acid and hydrolytic deben/olyation produced benæy 1 $\alpha$-D-pscudogalactal derivatives 5 and 6 . Treatment of these ally lic alcohol derivatives 3. 4. 5. and 6 with 4-nitrophenyl chloroformate and pyridine followed by sodium aride ${ }^{2}$ afforded the corresponding benzy] $4-O$-axidoformyl- $\alpha$-Dpscudoglycals 7. 8.9. and 10 in 69. 75. 85 . and $84 \%$ yicld. respectively (Scheme l).

These 4-O-azidoformyl-D-pseudoglycals 7. 8. 9. and 10

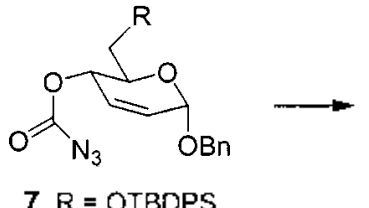

7. $R=$ OTBDPS

8. $R=H$

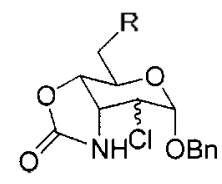

11. $R=$ OTBDPS

12. $R=H$
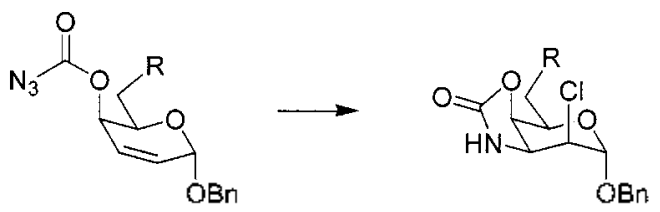

9. $R=$ OTBDPS

10. $R=H$

13. $R=$ OTBDPS

14. $\mathrm{R}=\mathrm{H}$

Scheme 2. Amidochlorination reactions 


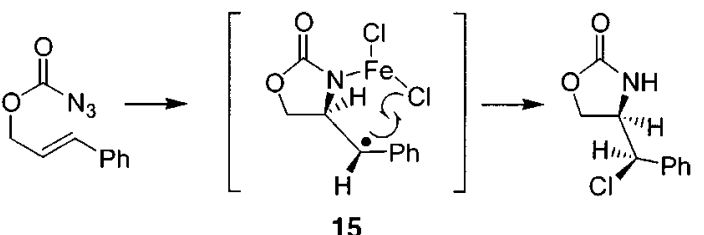

Scheme 3. Radical intermediate for sph addition.

were treated with 0.1 equivalents of iron (II) chloride and 1.5 equivalents of TMSCl in ethanol for $20 \mathrm{hr}$ at room tenperature and the reaction mixture was worked up by usual manner and purificd by column chromatography on silica gel to give cyclic carbamales of 3-amino-2-chloro- $\alpha$-Dglycopy ranosides $11,12.13$, and $1+$ in $30,32,30$. and $52 \%$ yicld respectively. Some of starting matcrials were recovered in mosi cases. and byproducts such as 4-O-carbanoyl derivatives and 6-lydroxyl compounds werc also oblained (Scheme 2).

The stercochemical outcome of this amidochlorination reaction is not fully understood. but T. Bach et al, proposed ${ }^{13}$ the radical intermediate 15 for the reaction of 3-phenyl-2propenyl axidoformate wilh iron (II) chloride and TMSCl. and thus the sm addition of amido group and chlorine to the double bond could be obtained (Scheme 3). In our 4-O)axidoformyl derivatives. the configuration of the 4-position could play an important role for the stercochemical outcome during this addition reaction. In casc of 7 and 8 . amido group and chlorine should approach to the double bond from the down face and in case of $\mathbf{9}$ and $\mathbf{1 0}$ from the upper lace. respectively. Howcrer. 'H-NMR studies show that in case of 11 and 12. 2-cpimers were obtained in a ratio of $8: 3$. whereas in case of 13 and 14. single isomers were isolated. These assignments were supporicd unambiguously by ${ }^{1} \mathrm{H}$ NMR spectrum of 13 which exhibited coupling constants. $J_{1.2}=6 \mathrm{H} \%, J_{2.3}=3 \mathrm{H} \%$ and $J_{3.4}=9 \mathrm{H} \%$ in good agrecment with cyclic carbanate of bensyl 3-amino-2-chloro- $6-()-(t-$ buty ldipheny Isily l)-2,3-dideoxy- $\alpha$-D-talopy ranoside. ${ }^{17}$

Even though this amidochlorination method gives rise to the low to moderate yields, it is quite simple and predictable compared to conventional photoly sis or themolysis. We are trying to identify the new horizon of this method by replacing iron (II) clloride with iron (II) bromide and the new amidobromination reaction of same substrates is in progress.

\section{Experimental Section}

The representative experimental procedures for the preparation of 4-O-azidoformy l derivatives and their amidochlorination reactions are as follows.

Benzyl 4-O-azidoformyl-6-O-( $t$-butyldiphenylsilyl)-2,3dideoxy- $\alpha$-D-erythro-hex-2-enopyranoside (7). To a stirred solution of benzyl 6-O-( $($-buty ldiphenylsilyl)-2.3-dideoxy$\alpha$-D-eny/hro-hex-2-enopyranoside $(3.0 .75 \mathrm{~g} .1 .58 \mathrm{mmol})$ and pyridine in benzene $(10 \mathrm{~mL})$ was added 4-nitrophenyl chloroformate $(0.64 \mathrm{~g} .3 .16 \mathrm{mmol})$ and the solution was stirred for $2.5 \mathrm{hr}$ at rt. Ethyl acetate $(20 \mathrm{~mL})$ was added followed by aqueous sodium bicarbonate solution and the organic layer was separated. Usual workup and craporation gave ycllow solid which was dissolved in DMF $(6 \mathrm{~mL})$ without further purification. Sodium aride (1.13 g. 15.8 mmol) was added and the solution was stirred for $19 \mathrm{hr}$ at 35 ${ }^{\circ} \mathrm{C}$. Aqueous ammonium chloride solution was added followed by chloroform and the organic layer was purified. Column chromatography of the crude syrup afforded colorless oily product in $69 \%$ yicld $(0.59 \mathrm{~g} .1 .09 \mathrm{mmol})$. IR $\left(\mathrm{cm}^{-1}\right.$ ): 2191. 2120 (aride). 1728 (carbonyl). ${ }^{1} \mathrm{H}$-NMR (300 $\mathrm{MH}$ \%. $\left.\mathrm{CDCl}_{3}, \delta . \mathrm{ppm}\right): 7.72-7,60(\mathrm{~m}, 4 \mathrm{H}), 7.4+-7.23(\mathrm{~m}$. l lH). $5.96-5.88(\mathrm{~m}, 2 \mathrm{H}, \mathrm{H}-2$ and $\mathrm{H}-3) .5 .40(\mathrm{~d} . J=9 \mathrm{H} / . \mathrm{H}-$ l). $5.13(\mathrm{~s} .1 \mathrm{H} . \mathrm{H}-4), 4.79(\mathrm{~d} . J=12 \mathrm{H} \% \mathrm{IH}$, ben $/ \mathrm{lic} \mathrm{H})$. $4.59(\mathrm{~d} . J=12 \mathrm{H} \% \mathrm{lH}$, ben $/ \mathrm{lic} \mathrm{H}), 4.10-4.02(\mathrm{~m}, \mathrm{lH}, \mathrm{H}-5)$. $3.79-3.76(\mathrm{~m} .2 \mathrm{H} . \mathrm{H}-6) .1 .07$ (s.) $) \mathrm{H} . t$-buly $\mathrm{l}$ ).

Cyclic carbamate of benzyl 3-amino-2-chloro-6-O-( $t$ butỵldiphenylsilyl)-2,3-dideoxy- $\alpha$-D-talopyranoside (13). A solution of bensyl $4-O$-azidolomy l- $6-O-(t-b u t y$ ldipheny $1-$ sily l)-2.3-didcoxy- $\alpha$-D-threo-hex-2-cnopy ranoside (9.0.33 g. $0.60 \mathrm{mmol})$ in cthanol $(10 \mathrm{~mL})$ was degassed with argon and cooled to $0^{\circ} \mathrm{C}$. Chlorotrimethy lsilane $(0.11 \mathrm{~mL}$. 0.90 mmol) and iron (II) chloride (7.6 mg. $0.06 \mathrm{mmol}$ ) were added and the solution was stirred for $20 \mathrm{hr}$ at $\mathrm{rt}$. A small amount of water was added. cthanol was craporated and the residue was cxtracted with ethyl acetate. Usual workup and column chromatography aftorded an oily product in $30 \%$ yicld (0.10 g. $0.18 \mathrm{mmol})$. [R ( $\left.\left.\mathrm{cm}^{-1}\right): 36\right] 4$ (brd. NH). 1769) (carbonyl). 1738 (carbonyl). 1465. 'H-NMR (300 MH\%. $\left.\mathrm{CDCl}_{3} . \delta . \mathrm{ppm}\right): 7.68-7.64(\mathrm{~m} .4 \mathrm{H}) .7 .44-7.36(\mathrm{~m} .6 \mathrm{H}) .7 .29$ (s. $5 \mathrm{H}) .5 .59$ (brd d. IH. D.O cxchangcable. NH). $4.90(\mathrm{~d} . J$ $=6 \mathrm{H} \% \mathrm{lH} . \mathrm{H}-\mathrm{l}) .4 .89(\mathrm{~d} . J=9 \mathrm{H} / . \mathrm{lH} . \mathrm{H}-4) .4 .75(\mathrm{~d} . J=12$ H $\%$ lH. benzylic H). 4.57 (d. $J=12 \mathrm{H} \%$. IH. bens lic H). 4.42 (dd. $J=9$ and $3 \mathrm{H} \% \mathrm{H}-3$ ). $3.99-3.95(\mathrm{~m} .2 \mathrm{H} . \mathrm{H}-2 . \mathrm{H}-5$ ). $3.9(0-3.80(\mathrm{~m} .2 \mathrm{H} . \mathrm{H}-6) .1 .06$ (s. $9 \mathrm{H}, t$-butyl).

Acknowledgment. Financial supports from the Korea Science and Engincering Foundation (Grant No. R0I-2000)(0049) and Brain Korca 2l Program (for H. W. Chung) arc gratefully acknowledged.

\section{References and Notes}

1. Koohang. A.: Stanchina. C. L.: Coatcs. R. M. Tetrolk'dron 1999. 55.9669 .

2. 13ergmeier S. C. Stanchina, 1). M. J. Org (them. 1999, 64. 2852.

3. I3ergmeier, S. C.: Stanchina, I) M. J. Org (7hm 1997.62. 4449.

4. Bergncicr. S. C. Stanchina. D. M. Tetrohedrom Lett. 1995.36. 4533 .

5. de Santis. M.: Fioravanti. S.: Pellacani. L.: Tardella. P. A. I.tu .J. Org. Chem. 1999, $27(6)$.

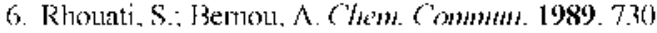

7. Williams, 1). R.: Rojas, C. M.: I3ogen, I. J. Org. (Them 1999. 64. 736.

8. De Clerce. P. T.: Deroosc. F. D. J. Org. (7km. 1995. 60. 321.

9. Kanl C.: Long. C. M.: Paul M.: Ring. C. M.: Tully. S. E.: Rojas. C. M. Org. $/ e^{2} t$. 2001, 3. 381 .

10. I. eviles-Agababa, 1i.: Menhaji, F.: Perlson. I.. N.: Rojas, C. M. Org. Lett. 2002. 4. 863.

11. Kozlowska-Gramsz. E.: Descotes. G. Tetwhedron Lett. 1981. 22. 563.

12. Kozlonska-Gramsz. E.: Descotes. G. Cam. J. Chent, 1982, 60. 
558.

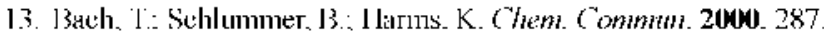

14. Ritter 'T. K.: Wong C.-H. Angen: Chem. Int Hid. 2001 40. 3518.

15. l'enier. R. J.: Prasad. N. J. ( / /tm. Soc. (C) 1969. 570.

16. Mitsunobu. O. Simhthesis 1981. 1.

17. Reaction of methỵl 4-O-azidoformyl-2.3.6-trideoxy-(x-D-throto- hex-2-enopvranoside with iron (II) bromide attorded eyclic earbamate of methyl 3-amino-2-brome-2.3 (6-trideoxy- $\alpha$-1)-talopsranoside as a cristal and the single $X$-ray erystallography of this erystalline product confinned the sm addition of amido group and bromine. 'H-NMR spectral data also showed same coupling constants (to le published). 